\title{
Whooping Crane Monument
}

by Dave Green, Department of Natural Resources, Regina

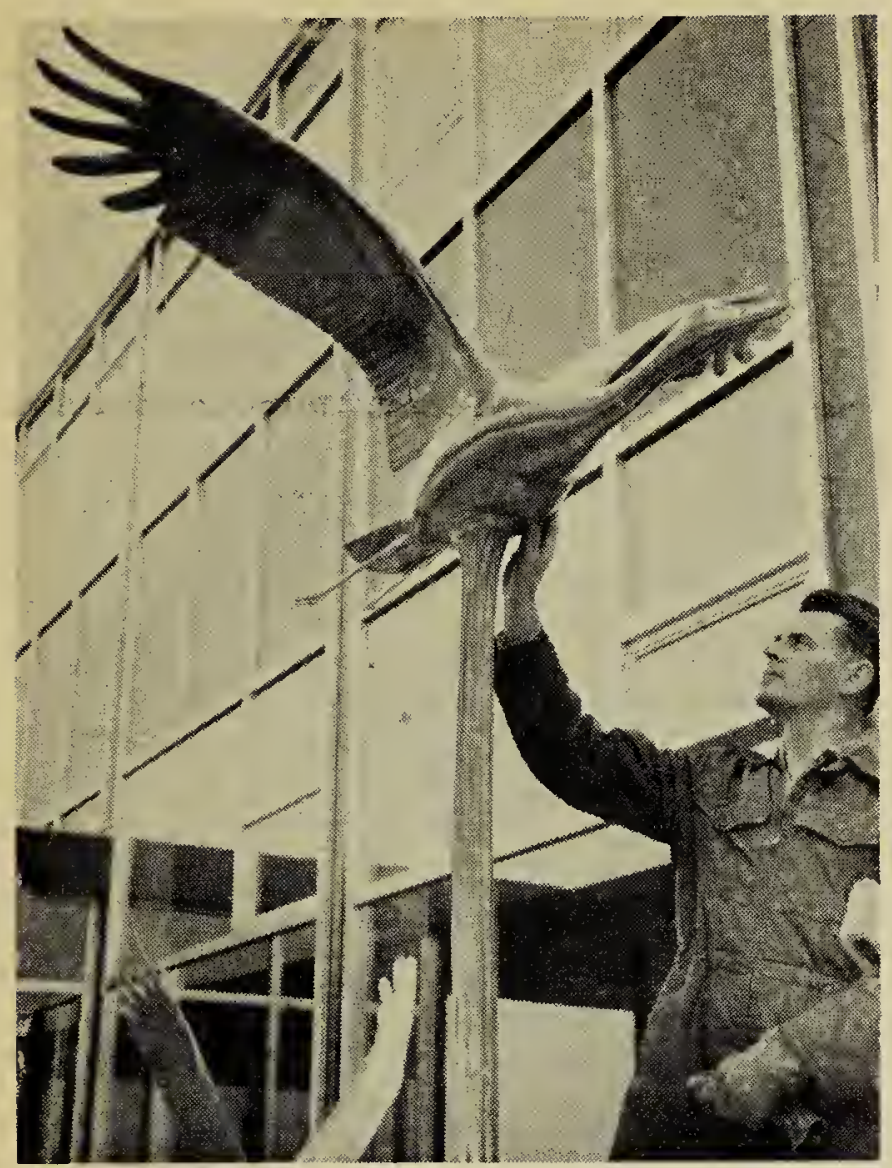

Sask. Photo Services

Sculptor W. Niessen and the Whooping Crane monument at the Regina City Airport.

Although the annual migration of the only wild Whooping Cranes (Grus americana) in North America carries the magnificent white birds over Saskatchewan twice yearly; few residents can expect a glimpse of them. Whooping Cranes are among the rarest of the world's living things: only 36 of these birds were counited last season on their southern wintering grounds. Canada's Department of Transport has recently honoured the species with a handsome monument at Regina's City Airport.

Two life-sized sculptured figures of the birds were created for the monument by Regina artist Wolfram Niessen, 38-year-old sculptor-naituralist employed by the Saskatchewan Museum of Natural History. The monument consists of one bird in the act of taking off and a second in full flight.

The design for the monument was conceived by Mrs. Betty Gillespie, a professional interior decoratior in Regina. Mrs. Gillespie visualized the statues as symbolizing the crossing

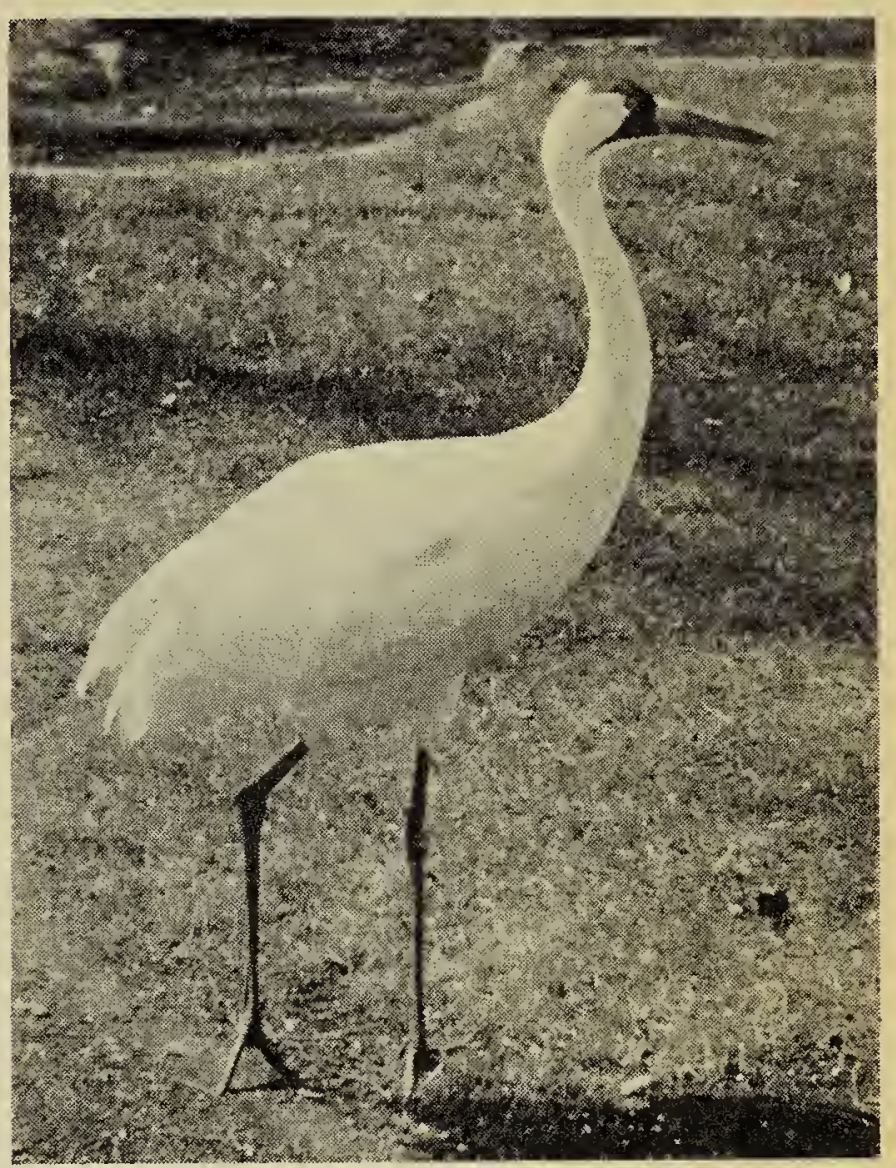

Photo by F. G. Bard

Captive Whooping Crane at the San Antonio Zoo, March, 1960.

point of one of the world's great bird migration routes and the east-west flight routes of Canada's commercial airlines. The Whooping Cranes, she felt, admirably represent all the birds that use the north-south flyway.

Almost a year was spent in preparing the monument. Mr. Niessen first modelled the cranes in plaster of paris over a steel frame. The plaster figures were then transferred into wax, retouched by the artisit and cast in aluminum by the St. Mark's Shop foundry at Lumsden. The foundry operator, John Nugent, is himself a sculptor and was well able to appreciate the difficulties of this undertaking. The task fulfilled the highest expectations of those concerned.

Now on display at the sculpture court at the airport, the cranes are an impressive addition to the world's bird monuments, including Salt Lake City's commemoration of the gulls that saved the early Mormon settlers from a plague of insects and the famous Passenger Pigeon memorial in Wisconsin. 